\title{
FAKTOR-FAKTOR YANG MEMENGARUHI PEMUDA MENJADIPENGANGGURAN DI PROVINSI BANTEN TAHUN 2018
}

\author{
(Factors Affecting Youth to Become Unemployed in Banten Province in 2018) \\ Muhammad Hasby Ashshiddiq ${ }^{1}$, Rani Nooraeni ${ }^{2}$ \\ Politeknik Statistika STIS ${ }^{1}$ \\ Politeknik Statistika STIS ${ }^{2}$ \\ Jakarta Timur, DKI Jakarta \\ E-mail: 15.8753@stis.ac.id
}

\begin{abstract}
ABSTRAK
Provinsi Banten menghadapi masalah terkait tingginya tingkat pengangguran, pada tahun 2018 Banten merupakan provinsi dengan Tingkat Pengangguran Terbuka (TPT) tertinggi di Indonesia. Tingkat pengangguran terbanyak di Banten didominasi oleh angkatan kerja berusia 16-30 tahun (pemuda) dibandingkan kelompok usia lainnya. Pemuda merupakan modal yang berharga bagi pembangunan karena mampu untuk lebih produktif dalam jangka panjang. Pemuda pengangguran berdampak buruk dalam jangka pendek karena masalah sosial dan ekonomi yang mereka hasilkan serta dalam jangka panjang kualitas pemuda yang buruk akan menghambat pertumbuhan dan pembangunan ekonomi daerah. Karena dampak buruk yang ditimbulkannya, maka permasalahan ini harus segera dicarikan solusinya. Penelitian ini bertujuan untuk mengetahui karakteristik demografi pengangguran pemuda di Provinsi Banten. Untuk mencapai tujuan tersebut maka digunakan analisis regresi logistik biner. Hasil penelitian menunjukkan bahwa karakteristik demografi jenis kelamin, usia, status perkawinan, pendidikan, dan status wilayah tempat tinggal signifikan berpengaruh terhadap status kerja pemuda di Provinsi Banten pada tahun 2018. Angkatan kerja pemuda di Provinsi Banten yang memiliki kecenderungan untuk menjadi pengangguran adalah yang pemuda yang berjenis kelamin laki-laki, belum menikah, tinggal di daerah perdesaan, berpendidikan tinggi atau lebih dari SMP, dan berada pada rentang usia antara 16 hingga 19 tahun
\end{abstract}

Kata kunci: angkatan kerja pemuda, regresi logistik biner, pengangguran

\begin{abstract}
Banten faces a problem related to the high unemployment rate, in 2018 Banten is province with the highest unemployment rate in Indonesia. Youth is a valuable asset for development because it is able to be more productive in the long run. Youth unemployment have a negative impact in the short term due to social and economic problems that they produce as well as in long-term youth poor quality will constrain the growth and economic development of the region. Because of the adverse effects for the region and the community, a solution must be immediately sought This study aims to determine the demographic characteristics of youth unemployment in Banten Province. To achieve these objectives, binary logistic regression analysis was used The results showed that the demographic characteristics of sex, age, marital status, education, and status of residential areas significantly affected the working status of youth in Banten Province in 2018. The youth workforce in Banten Province which has a tendency to become unemployed is the one who is male, unmarried, lives in a rural area, has a higher education or more than junior high school, and is in the age range between 16 and 19 years old.
\end{abstract}

Keywords: Youth workforce, binary logistic regression, unemployment 


\section{PENDAHULUAN}

Undang-Undang nomor 40 tahun 2009 tentang Kepemudaan pasal 1 ayat 1 menyatakan, pemuda adalah seseorang yang berusia antara 16 sampai 30 tahun. Berdasarkan data proyeksi jumlah penduduk yang dikeluarkan oleh Badan Perencanaan Pembanguna Nasioal (Bappenas) pada tahun 2018 jumlah penduduk Indonesia mencapai 265 juta jiwa. Dari total tersebut, menurut hasil Susenas (Survei Sosial Ekonomi Nasional) tahun 2018, Indonesia adalah rumah bagi 63,82 juta jiwa pemuda. Jumlah tersebut merupakan satuperempat dari total penduduk Indonesia. Berdasarkan data yang sama pada tahun 2018 , separuh pemuda Indonesia bekerja $(52,87$ persen), sisanya aktif sekolah, mengurus rumah tangga, serta sibuk mencari dan mempersiapkan pekerjaan. Pemuda yang terlibat dalam kegiatan ekonomi cukup tinggi, hal ini dinyatakan dengan nilai TPAK pemuda sebesar 60,10 persen. Artinya, sekitar tiga dari lima pemuda sedang bekerja, mempersiapkan pekerjaan, atau mencari pekerjaan. Memiliki karakteristik pemuda seperti itu, akan menjadi modal berharga bagi Indonesia untuk dapat memacu pertumbuhan dan pembangunan ekonomi kedepannya.

Namun, modal berharga tersebut akan berubah menjadi bencana, jika tidak diiringi dengan jumlah lapangan pekerjaan yang tersedia. Jumlah tenaga kerja yang tidak seimbang dengan lapangan pekerjaan yang tersedia akan menimbulkan masalah kompleks, yaitu pengangguran. Ningrum (2013) menyatakan bahwa jika tidak ada kebijakan makro dan mikro yang berpihak terhadap tenaga kerja, dikuatirkan jumlah pengangguran muda akan terus bertambah dan berdampak pada berbagai hal termasuk permasalahan di masyarakat. Pemuda pengangguran juga cenderung menarik diri dari kehidupan sosial dengan menurunkan partisipasi mereka dalam berdemokrasi politik, keinginan untuk bunuh diri meningkat, serta menuju ke tindakan kriminalitas. Sesuai yang dikatakan oleh Sukirno (2011) bahwa pengangguran berdampak pada meningkatnya tingkat kriminalitas di Indonesia. Dalam jangka panjang, tingkat kesejahteraan masyarakat yang rendah karena banyaknya pengangguran akan meningkatkan persentase kemiskinan. Pengangguran menyimpan potensi untuk menjadi bencana di masyarakat jika dibiarkan. Berdasarkan hasil survei angkatan kerja nasional (Sakernas) tingkat pengangguran tertinggi masih berada berdasarkan rentang usia masih didominasi oleh pemuda Indonesia, dengan TPT 28.27 , 16.61, dan 6.31 pada tiga kelompok umur angkatan kerja termuda (15-29).

Permasalahan penyediaan lapangan pekerjaan yang layak dan juga memenuhi merupakan salah satu dari fokus dari program pembangunan berkelanjutan (SDG'S). Fokus tersebut dapat dilihat dari salah satu tujuan pembangunan berkelanjutan (Suistainable Development Goals) yang ditetapkan pada tahun 2015 silam. Termaktub dalam tujuan ke delapan dari Suistainable Development Goals (SDG's) yang berisi : Mendukung pertumbuhan ekonomi yang inklusif dan berkelanjutan, tenaga kerja penuh dan produktif dan pekerjaan yang layak bagi semua. Dimana salah satu target dari tujuan tersebut yang tercantum dalam target ke lima adalah mencapai ketenagakerjaan secara penuh dan produktif dan pekerjaan layak bagi seluruh perempuan dan lakilaki, termasuk untuk kaum muda dan orang dengan disabilitas, juga kesetaraan upah bagi pekerjaan yang mempunyai nilai yang sama. Dan target ke enam yaitu pada tahun 2020 secara substansial mengurangi proporsi usia muda yang tidak bekerja, tidak berpendidikan atau terlatih.

Salah satu daerah di Indonesia yang bermasalah dengan tingkat pengangguran yang tinggi adalah provinsi Banten. Berdasarkan laporan kajian ekonomi dan keuangan regional regional provinsi Banten, Ekonomi Provinsi Banten pada triwulan IV 2018 tumbuh lebih tinggi dibandingkan pertumbuhan nasional dan kawasan Jawa. Jika dibandingkan dengan tahun 2017, pertumbuhan ekonomi di Banten tahun 2018 juga meningkat. Dari sisi kualitas hidup masyarakat terlihat adanya peningkatan sebagaimana tergambar dari IPM Provinsi Banten yang secara konsisten menunjukkan tren peningkatan dan selalu lebih tinggi dari IPM Nasional. Peningkatan kesejahteraan juga dicerminkan dari menurunnya angka gini ratio pada September 2018 ke level terendah sejak tahun 2010. Hal ini menunjukkan bahwa kondisi makro provinsi Banten yang dilihat cukup baik, bahkan di antara provinsi-provinsi di Pulau Jawa. Namun permasalahan pengangguran di Banten masih terus 
terjadi. Semenjak terbentuk pada tahun 2000 lalu, tingkat pengangguran terbuka (TPT) di provinsi Banten selalu menjadi lebih tinggi dibandingkan TPT nasional. Bahkan pada tahun 2018 menurut data BPS TPT Banten merupakan yang tertinggi di Indonesia dengan TPT 8,52 jauh diatas TPT nasional yang hanya 5,34. Pengangguran yang tinggi di provinsi Banten ternyata dipengaruhi oleh tinggi nya pengangguran yang berusia muda (pemuda). Provinsi Banten memiliki TPT pemuda tahun 2018 sebesar 19.39 persen. Pada tahun 2018 angka TPT pemuda provinsi Banten juga merupakan nilai tertinggi kedua di bawah Provinsi Jawa Barat, dan di provinsi Banten nilai nya cenderung meningkat semenjak tahun 2014. Peran pemuda adalah sebagai tulang punggung dari keluarga dan masyarakat. Namun dengan tidak memiliki pekerjaan dan penghasilan, pemuda-pemuda ini hanya akan menjadi beban dalam masyarakat. Pemuda pengangguran akan menjadi penyebab dari kemiskinan, menciptakan kriminalitas dan mendorong keresahan di masyarakat.

Menurut Mankiw (2012), pengangguran merupakan bentuk pembuangan terhadap sumber daya manusia yang ada. Pembuangan terhadap sumber daya karena pemuda pengangguran tidak mampu untuk produktif karena tidak memiliki pekerjaan. Pemuda yang pengangguran berarti pemuda tersebut tidak bersekolah atau melanjutkan pendidikan, sehingga potensi mereka tertahan dan tidak bisa dimanfaatkan untuk masa depan mereka. Pendidikan serta pelatihan terhadap pemuda merupakan salah satu bentuk investasi sumber daya manusia, jika pada saat sekarang kualitas angkatan kerja pemuda terus ditingkatkan maka hasilnya diharapkan akan dapat meningkatkan produktivitas. Pembuangan terhadap sumber daya dan potensi kepemudaan di Banten akan terus terjadi jika angka pengangguran pemuda tetap tinggi.

Fila et Al (2016) menemukan fakta dimana angkatan kerja berusia muda (20-24 tahun) cenderung untuk menjadi pengangguran dibandingkan dengan usia lainnya. Usia mencerminkan keadaan pengalaman dan pengetahuan yang didapatkan seseorang, seiring bertambahnya usia maka semakin banyak pula pengalaman dan pengetahuan yang dimiliki orang tersebut. Tenaga kerja yang berusia muda, tentu memiliki kekurangan dalam hal kepemilikian pengalaman dan pengetahuan dibandingkan dengan yang berusia lebih tinggi. Selain pendidikan dan pengalaman, masih banyak faktor yang dapat berpengaruh terhadap pengangguran di suatu daerah, baik faktor makro maupun faktor mikro (individu). Seperti yang diungkapkan oleh Shita \& Dereje (2018) bahwa usia yang muda bagi para lulusan baru dan belum memiliki pengalaman kerja menyebabkan mereka menjadi sulit dalam mendapatkan pekerjaan. Sementara itu di Tanzania dalam penelitian yang dilakukan oleh Msigwa dan Kipesha (2013) angkatan kerja muda cenderung untuk menjadi pengangguran jika dia berjenis kelamin laki-laki, tinggal di perkotaan, memiliki tingkat pendidikan yang rendah, tidak memiliki skill dan belum menikah. Dari latar belakang yang telah dijabarkan sebelumnya maka diperlukan penelitian untuk dapat mengetahui bagaimana karakteristik dari angkatan kerja pemuda di provinsi Banten serta variabel apa saja yang berpengaruh dan kecenderungannya terhadap pengangguran pemuda di Provinsi Banten pada tahun 2018.

\section{METODE}

\section{Landasan Teori}

Definisi tenaga kerja yang digunakan pada penelitian ini berdasarkan pada definisi yang digunakan oleh Badan Pusat Statistik (BPS). BPS mendefinisikan tenaga kerja dengan mengacu pada The Labor Force Concept dari International Labor Organization (ILO). The Labor Force Concept membagi penduduk menjadi dua kelompok, yaitu penduduk usia kerja dan bukan usia kerja. Penduduk usia kerja adalah penduduk yang berusia antara 15-64 tahun, dan bukan usia kerja berusia kurang dari 15 tahun dan lebih dari 64 tahun. Penduduk usia kerja dibagi menjadi dua lagi berdasarkan kegiatan utama yang sedang dilakukan yaitu angkatan kerja dan bukan angkatan kerja. Konsep pemuda memiliki beberapa pengertian yang berbeda di setiap negara. PBB (1992) mendefinisikan pemuda (youth) sebagai penduduk usia 15-24 tahun. Sementara ILO mendefinisikan penduduk usia muda berada pada kelompok usia 15-29 tahun (ILO,2007). Pada penelitian ini definisi pemuda menggunakan definisi yang diatur oleh UU di Indonesia. Berdasarkan Undang-Undang no 40 tahun 2009 yang menyatakan bahwa pemuda adalah penduduk Indonesia yang memasuki periode penting pertumbuhan dan perkembangan yaitu berusia 16-30 tahun. Pemuda yang 
menganggur adalah angkatan kerja yang berusia 16-30 tahun dan tidak memiliki pekerjaan, maupun usaha,sedang mencari pekerjaan atau mempersiapkan usaha maupun yang sudah memiliki pekerjaan, namun belum mulai bekerja.

\section{Ruang Lingkup Penelitian}

Penelitian ini bertujuan untuk menganalisis faktor-faktor yang memengaruhi status kerja dan kecenderungannya terhadap pemuda di provinsi Banten. Faktor-faktor yang diduga mempengaruhi tersebut berasal dari penelitian-penelitian sebelumnya. Variabel yang digunakan dalam penelitian ini terbagi menjadi variabel dependen dan independen. Variabel dependen adalah status kerja pemuda di provinsi Banten tahun 2018. Sementara variabel independen terdiri dari jenis kelamin responden, umur, status kepala rumah tangga, status kawin, tingkat pendidikan, klasifikasi wilayah tempat tinggal dan pengalaman kerja yang dimiliki. Berdasarkan tujuan dari penelitian ini, maka data yang digunakan adalah data individu angkatan kerja yang berusia dilingkup pemuda di provinsi Banten.

Sumber data dari penelitian ini menggunakan raw data dari hasil Survei angkatan kerja nasional (Sakernas) bulan Agustus tahun 2018, dengan sampel yang diambil adalah individu dengan kategori angkatan kerja pada usia 16-30 tahun. Jumlah total angkatan kerja yang tersampel berjumlah 2.163 individu.

\section{Metode Analisis}

Metode analisis pada penelitian ini menggunakan dua metode, yaitu metode analisis deskriptif dan metode analisis inferensia. Analisis deskriptif digunakan untuk melihat gambaran dari karakteristik pemuda di provinsi Banten. Analisis deskriptif juga digunakan untuk melihat hubungan antara variabel-variabel dependen pada penelitian ini dengan status kerja pemuda.. Analisis inferensia pada penelitian ini menggunakan analisis regresi logistik biner. dan digunakan untuk mengetahui pengaruh dari variabel-variabel dependen serta kecenderungannya terhadap status kerja pemuda di Banten.

\section{Model Regresi Logistik Biner}

Dalam Model Regresi Logistik Biner variabel dependennya berupa data kualitatif dikotomi yaitu bernilai 1 untuk menyatakan status kerja "pengangguran" dan nilai 0 untuk menyatakan status kerja "bukan pengangguran". Variabel dependen akan mengikuti distribusi bernoulli dengan fungsi probabilitas sebagai berikut :

$$
f\left(y_{t}\right)=\pi\left(x_{i}\right)^{y_{i}}\left(1-\pi\left(x_{i}\right)\right)^{1-y_{i}}, \mathrm{y}_{\mathrm{i}}=0,1
$$

Dengan $\pi\left(\mathrm{x}_{\mathrm{i}}\right)$ adalah peluang kejadian ke-1 $\mathrm{y}_{\mathrm{i}}$ adalah peubah acak ke-i

maka, model regresi logistik adalah sebagai berikut.

$$
\pi(x)=\frac{\exp \left(\beta_{0}+\beta_{1} x_{1}+\ldots+\beta_{p} x_{p}\right)}{1+\exp \left(\beta_{0}+\beta_{1} x_{1}+\ldots+\beta_{p} x_{p}\right)}
$$

Persamaan (1) diatas kemudian akan ditransformasi yang dikenal dengan transformasi logit $\pi$ $(x)$ untuk memperoleh fungsi $\mathrm{g}(x)$ yang linear dalam parameternya, sehingga mempermudah pendugaan parameter regresi yang dirumuskan sebagai berikut 


$$
g(x)=\ln \left[\frac{\pi(x)}{1-\pi(x)}\right] \beta_{0}+\beta_{1} x_{1}+\ldots+\beta_{p} x_{p}
$$

Untuk menduga parameter-parameter yang terdapat dalam model regresi logistik, digunakan metode Maximum Likelihood Estimator (MLE). Karena estimator parameter yang dihasilkan pada metode MLE belum menghasilkan estimator yang linier, maka tahap selanjutnya adalah dengan melakukan iterasi dengan bantuan perangkat lunak statistik, sehingga didapatkan estimator yang maksimum dan linear.

\title{
Uji Signifikansi
}

Menguji signifikansi dari parameter-parameter tersebut menggunakan dua uji, yaitu uji rasio likelihood atau uji G untuk menguji secara serentak. Sementara uji Wald digunakan untuk menguji secara parsial. (Agresti, 2000).

\section{Likelihood ratio test}

Uji rasio likelihood adalah uji yang membandingkan model yang mengandung variabel independen dengan model yang tidak mengandung variabel independen. menggunakan hipotesis sebagai berikut :

Hipotesis

$\mathrm{H}_{0}: \beta_{0}=\beta_{1}=\ldots=\beta_{\mathrm{p}}=0$

$\mathrm{H}_{1}$ : minimal satu $\beta_{\mathrm{j}} \neq 0$, dengan $\mathrm{j}=0,1, \ldots, \mathrm{p}$

Statistik uji

$G=-2 \ln$ (likelihood tanpa variabel independen/likelihood dengan variabel independen)

Kriteria Uji

Tolak $\mathrm{H}_{0}$ jika nilai $\mathrm{G}>X^{2}(a, p)$ atau jika nilai $\mathrm{p}$-value $<\mathrm{a}(5 \%)$

\section{Uji Wald}

Uji Wald digunkan untuk mengetahui peranan masing-masing peranan variabel independen terhadap variabel dependen

Hipotesis

$H_{0}: \beta_{j}=0$, dengan $\mathrm{j}=1,2, \ldots, \mathrm{p}$

$H_{1}: \beta_{j} \neq 0$, dengan $j=1,2, \ldots, p$

Statistik Uji

$$
W=\left[\frac{\hat{\beta}_{1}}{s e \hat{\beta}_{1}}\right]^{2} \sim \mathrm{X}^{2}(1)
$$

\author{
Kriteria Uji \\ Tolak $\mathrm{H}_{0}$ jika nilai $\mathrm{W}>X^{2}(a, p)$ atau jika nilai $\mathrm{p}$-value $<\mathrm{a}(5 \%)$
}

\section{Odds Rasio}

Ukuran yang digunakan dalam menginterpretasi koefisien variabel independen adalah Odds ratio. Odds ratio (rasio kecenderungan) menunjukkan perbandingan peluang munculnya suatu kejadian dengan peluang tidak munculnya kejadian tersebut. Jika nilai odds ratio $<1$, maka antara variabel dependen dan variabel independen terdapat hubungan negatif setiap kali perubahan nilai variabel independen $(\mathrm{X})$ dan jika nilai odds ratio $>1$, maka antara variabel dependen dan 
independen teradapat hubungan positif setiap kali perubahan nilai variabel independen $(X)$. Nilai odds ratio dapat diformulasikan sebagai berikut. (Agresti, 2000)

$$
O R=\frac{\frac{\pi(x=1)}{[(1-\pi(x=1))]}}{\frac{\pi(x=0)}{[(1-\pi(x=0))]}}
$$

Keterangan :

$\pi(\mathrm{x}) \quad$ : peluang kejadian sukses

OR: nilai Odds Ratio

$x$ : nilai variabel independen

\section{Goodness of fit}

Untuk menguji kesesuaian model, Hosmer and Lemeshow (2000) memberikan beberapa pendekatan berbeda dalam menguji seberapa fit suatu model, diantaranya adalah hasmer and lemeshow test, tabel klasifikasi dan kurva ROC. Pengujian secara statistik, menggunakan Hosmer \& Lemeshow test. Pada pengujian ini, hipotesis nol akan ditolak jika a atau p-value kurang dari $a(0,05)$ dengan tingkat kepercayaan 95 persen. Model akan dinyatakan fit jika hasil uji nya adalah gagal tolak $\mathrm{HO}$.

Sementara pada tabel klasifikasi nilai estimasi peluang digunakan untuk memprediksi keanggotaan kelompok. Model dinyatakan fit jika model dapat memprediksi keanggotaan kelompok secara akurat menurut beberapa kriteria yang ada. Dalam tabel klasifikasi model dianggap tepat jika memprediksi observasi yang "sukses" untuk masuk ke kategori "sukses: dan observasi yang "tidak sukses" ke dalam observasi yang "tidak sukses" secara tepat.

Kurva Receiver Operating Curve (ROC) menurut Hosmer dan Lemeshow merupakan deskripsi yang lebih lengkap dalam mengenai akurasi ketepatan klasifikasi model berdasarkan luas area dibawah kurva ROC. Luas area di bawah area kurva ROC memiliki rentang nilai antara 0 dan 1. Berdasarkan klasifikasi yang dijabarkan maka luas area dibawah kurva ROC dapat dikategorikan sebagai berikut :

$$
\begin{array}{ll}
1: R O C=0,5 & \text {, tidak ada diskriminasi } \\
2: 0,7 \leq R O C \leq 0,8 & \text {, diskriminasi dapat diterima } \\
3: 0,8 \leq R O C \leq 0,9 & \text {, diskriminasi baik } \\
4: \operatorname{ROC} \geq 0,9 & \text {, diskriminasi sangat baik }
\end{array}
$$

\section{HASIL DAN PEMBAHASAN}

Gambaran Umum status bekerja Pemuda di Provinsi Banten tahun 2018

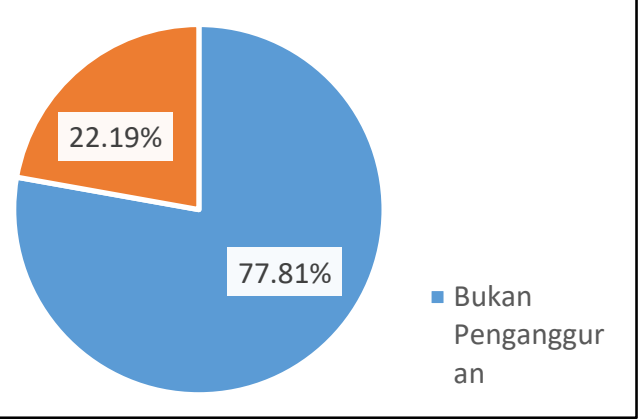

Sumber :Sakeras 2018 (diolah) 
Gambar 1. Persentase Pemuda menurut status kerja di provinsi Banten tahun 2018

Berdasarkan Gambar 1 kita bisa melihat bahwa 77,37 persen dari pemuda di provinsi Banten berstatus bukan pengangguran. Sementara sisanya masih mencari pekerjaan, sedang mempersiapkan usaha, sudah merasa tidak mampu untuk mendapatkan pekerjaan, ataupun sudah memiliki pekerjaan tapi belum mulai untuk bekerja pada saat pencacahan. Berdasarkan nilai yang mencapai 22,63 persen, dapat dikatakan satu dari lima pemuda di Banten tahun 2018 menganggur.

Variabel-Variabel yang Memengaruhi Status Kerja pada Pemuda Usia 16-30 Tahun di Provinsi Banten tahun 2018

Berdasarkan hasil olahan data Sakernas Agustus 2018 angkatan kerja pemuda di provinsi Banten lebih banyak berjenis kelamin laki-laki, berusia 24-30 tahun, bukan kepala rumah tangga, belum pernah menikah serta memiliki pendidikan lebih dari SMP sederajat, tinggal di wilayah perkotaan dan tidak punya pengalaman kerja.

Angkatan kerja pemuda di provinsi Banten masih didominasi laki-laki dengan persentase mencapai 64,1 persen. jika dilihat dari kelompok umur, pemuda yang berstatus angkatan kerja di Banten hampir setengah dari total angkatan kerja, dengan persentase mencapai 44,3 persen. hanya 7,9 persen saja pemuda yang berstatus sebagai kepala rumah tangga dan hanya 32 persen dari mereka yang pernah menikah sebelumnya. Ini menunjukkan bahwa banyak pemuda di Banten yang belum menanggung beban sebagai pemimpin dalam keluarga. Tingkat pendidikan pemuda Banten cukup baik dengan 60 persen merupakan lulusan SMA atau lebih. Namun dari pengalaman kerja, hanya 38,8 persen saja yang pernah punya pengalaman kerja sebelumnya. Kita bisa melihat bahwa 67,5 persen angkatan kerja pemuda di Provinsi Banten tinggal di daerah perkotaan.

Tabel 1. Karakteristik Angkatan Kerja Pemuda menurut Variabel Independen

\begin{tabular}{|c|c|c|}
\hline Variabel & Kategori (dummy variable) & Persentase \\
\hline (1) & (2) & (3) \\
\hline \multirow[t]{2}{*}{ Jenis Kelamin } & Perempuan $(0)^{*}$ & $35,9 \%$ \\
\hline & Laki-Laki (1) & $64,1 \%$ \\
\hline \multirow[t]{3}{*}{ Kelompok umur } & $16-19(00)^{*}$ & $16,4 \%$ \\
\hline & $20-24(10)$ & $39,3 \%$ \\
\hline & $25-30(01)$ & $44,3 \%$ \\
\hline \multirow{2}{*}{$\begin{array}{l}\text { Status Kepala Rumah } \\
\text { Tangga }\end{array}$} & Kepala Rumah Tangga $(0)^{*}$ & $92,1 \%$ \\
\hline & Bukan KRT & $7,9 \%$ \\
\hline \multirow[t]{2}{*}{ Status Kawin } & Pernah Kawin & $32,0 \%$ \\
\hline & Belum Kawin & $68,0 \%$ \\
\hline \multirow[t]{2}{*}{ Pendidikan Tertinggi } & $>$ SMP & $60,0 \%$ \\
\hline & $<=$ SMP $\quad(1)$ & $40,0 \%$ \\
\hline \multirow[t]{2}{*}{ Klasifikasi Wilayah } & Perdesaan & $32,5 \%$ \\
\hline & Perkotaan & $67,5 \%$ \\
\hline \multirow[t]{2}{*}{ Pengalaman Kerja } & Punya Pengalaman & $38,8 \%$ \\
\hline & Tidak Punya Pengalaman (1) & $61,2 \%$ \\
\hline
\end{tabular}

*): Kategori referensi 
Tabel 2. Karakteristik Angkatan Kerja Pemuda berdasarkan Status Kerja dan Variabel independen di Provinsi Banten tahun 2018

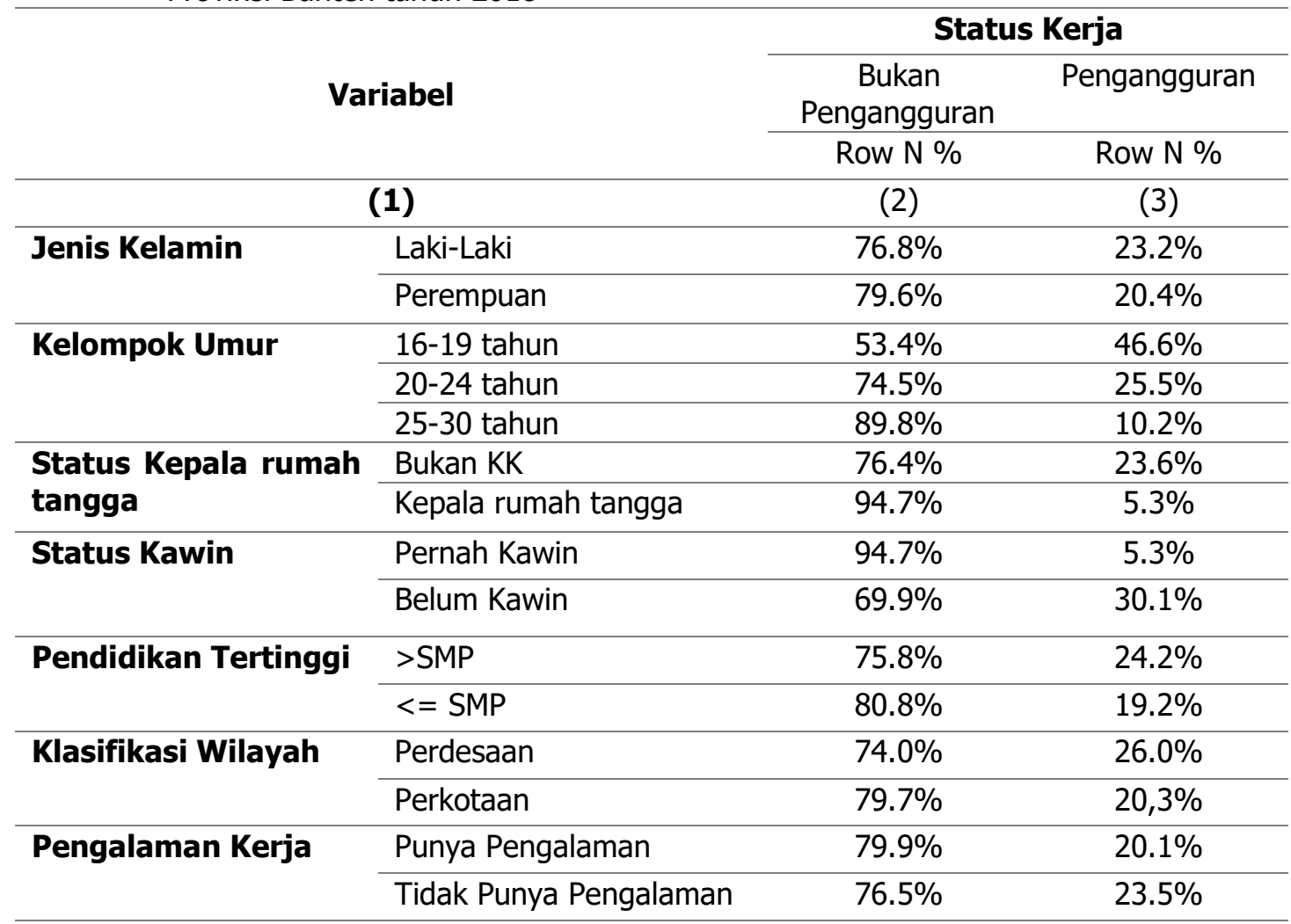

Sumber : Sakernas 2018 (diolah)

Berdasarkan Tabel 2, dapat dilihat bahwa persentase pemuda perempuan yang menjadi pengangguran adalah sebesar 20,4 persen. Sementara itu, persentase pemuda laki-laki yang menjadi pengangguran sedikit lebih banyak dibandingkan perempuan, dengan persentase mencapai 23,2 persen. Kita dapat melihat bahwa baik pemuda laki-laki maupun pemuda perempuan memiliki proporsi status bekerja yang tidak jauh berbeda.

Persentase pengangguran paling tinggi berada pada kelompok umur 16-19 tahun, yaitu hampir setengah dari total angkatan kerja di usia tersebut, dengan persentase sebesar 46,6 persen Sementara itu proporsi tenaga kerja semakin berkurang pada kelompok umur selanjutnya. Pada kelompok umur 20-24 tahun, persentase penganggurannya sebesar 25,5 persen. Dan pada kelompok umur usia 25-30 tahun, persentase angkatan kerja yang menganggur tinggal sebesar 10,2 persen saja.

Pemuda yang belum kawin dan pengangguran mencapai 30,1 pesen. Sementara itu pemuda yang berstatus pernah kawin dan pengangguran hanya mencapai angkat 5,3 persen, atau dapat dikatakan bahwa pemuda yang telah kawin 95 persennya sudah memiliki pekerjaan atau usaha. Fenomena ini menunjukkan bahwa status kawin sangat berpengaruh terhadap status kerja seorang pemuda.

Persentase pemuda berstatus kepala rumah tangga dan berstatus sebagai pengangguran hanya mencapai 5,3 persen dan sisanya sebesar 94,7 persen berstatus bekerja. Sementara itu, pemuda yang tidak berstatus kepala rumah tangga dan berstatus sebagai pengangguran adalah sebanyak 23,1 persen dan 76,4 persen sisanya berstatus bekerja. Hasil deskriptif ini menunjukkan bahwa status sebagai pemimpin keluarga memiliki pengaruh terhadap pengangguran pemuda di provinsi Banten.

Di provinsi Banten, pemuda dengan pendidikan terakhir SMP ke bawah terdapat 19,2 persen yang berstatus sebagai pengangguran. sementara itu pemuda dengan tingkat pendidikan terakhir minimal SMA, terdapat 24,2 persen yang berstatus sebagai pengangguran, kita bisa melihat bahwa masih banyaknya jumlah pengangguran terdidik di provinsi Banten pada tahun 2018. Pengangguran 
terdidik yang banyak adalah salah satu bentuk penyia-nyiaan terhadap sumber daya manusia yang berkualitas.

Persentase pengangguran di wilayah pedesaan adalah sebesar 26 persen dan 74 persennya berstatus sebagai pekerja atau bekerja. Sementara itu, didaerah perkotaan persentase pemuda penganggurannya sebanyak 20,3 persen dan yang menjadi pekerja sebanyak 79,7 persen. persentase pengangguran di daerah pedesaan jauh lebih banyak dibandingkan dengan di daerah perkotaan.

Dari keseluruhan pemuda usia 16-30 tahun di Banten dan tidak punya pengalaman kerja sebelumnya, terdapat 76,5 persen yang berstatus bekerja, sementara sisanya sebesar 23,5 persen berstatus sebagai pengangguran. Sementara itu, dari pemuda yang memiliki pengalaman kerja, terdapat 20,1 persen yang berstatus sebagai pengangguran, dan 79,1 persen yang berstatus bekerja.

\section{Pengaruh Variabel-Variabel Dependen terhadap Status kerja Pemuda usia 16-30 Tahun di Provinsi Banten dengan Regresi Logistik Biner}

\section{Model Regresi Logistik Biner}

Berdasarkan hasil penelitian ini, dengan memasukkan seluruh variabel yang dianggap memengaruhi status kerja pemuda di Banten, didapatkan model persamaan regresi logistik biner sebagai berikut :

$$
\begin{gathered}
\hat{g}(D)=-0,997+0,257 D 1 *-0,882 D 21 *-1,555 D 22 *-0,584 D 3+ \\
1,398 D 4-0,442 D 5 *-0,476 D 6 *-0,181 D 7
\end{gathered}
$$

\section{Uji Kesesuaian Model (Goodnes of Fit)}

\section{Hosmer and Lemeshow test}

Tabel 3. Nilai Statistik uji Hosmer and Lemeshow

\begin{tabular}{cccc}
\hline Step & Chi-square & df & Sig. \\
\hline $\mathbf{( 1 )}$ & $(2)$ & $(3)$ & $(4)$ \\
\hline $\mathbf{1}$ & 7,621 & 8 & 0,471 \\
\hline
\end{tabular}

Kesimpulan : Hasil pada tabel menunjukkan bahwa nilai signifikansi lebih dari $a=5$ persen. Maka dapat disimpulkan dengan tingkat signifikansi 5 persen, terdapat cukup bukti untuk menyatakan bahwa model yang digunakan cocock ( fit) untuk digunakan pada penelitian ini.

\section{Classification Table}

Selain menggunakan uji hosmer dan lemeshow, pada penelitian ini juga menguji kesesuian model dengan menggunakan tabel klasifikasi dan area kurva ROC. Tabel 4 menunjukkan hasil dari tabel klasifikasi

Tabel 4. Hasil Tabel Klasifikasi

\section{Predicted}

Observed

Status kerja

Bukan pengangguran Pengangguran

\begin{tabular}{|c|c|c|c|c|c|}
\hline (1) & & (2) & (3) & (4) & (5) \\
\hline \multirow{3}{*}{$\begin{array}{c}\text { Step } \\
1\end{array}$} & \multirow{2}{*}{$\begin{array}{l}\text { Status } \\
\text { kerja }\end{array}$} & $\begin{array}{c}\text { Bukan } \\
\text { pengangguran }\end{array}$ & 1611 & 72 & 95,7 \\
\hline & & Pengangguran & 391 & 89 & 18,5 \\
\hline & \multicolumn{2}{|c|}{ Overall Percentage } & & & 78,6 \\
\hline
\end{tabular}

Percentage Correct 
Nilai yang dilihat dari tabel klasifikasi adalah nilai overral percentage. Overall Percentage adalah metode yang dapat memeriksa kesesuaian model dalam mengkalasifikasikan objek secara benar ke dalam setiap kategori variabel dependen. Pada tabel 4 kita bisa mengetahui bahwa nilai overral percentage sebesar 78,6 persen, Menurut Hosmer batas minimal overral percentage untuk model dapat digunakan adalah 50 persen. Maka, model yang terbentuk dapat digunakan untuk menggambarkan kecenderungan pemuda untuk menganggur.

ROC curve

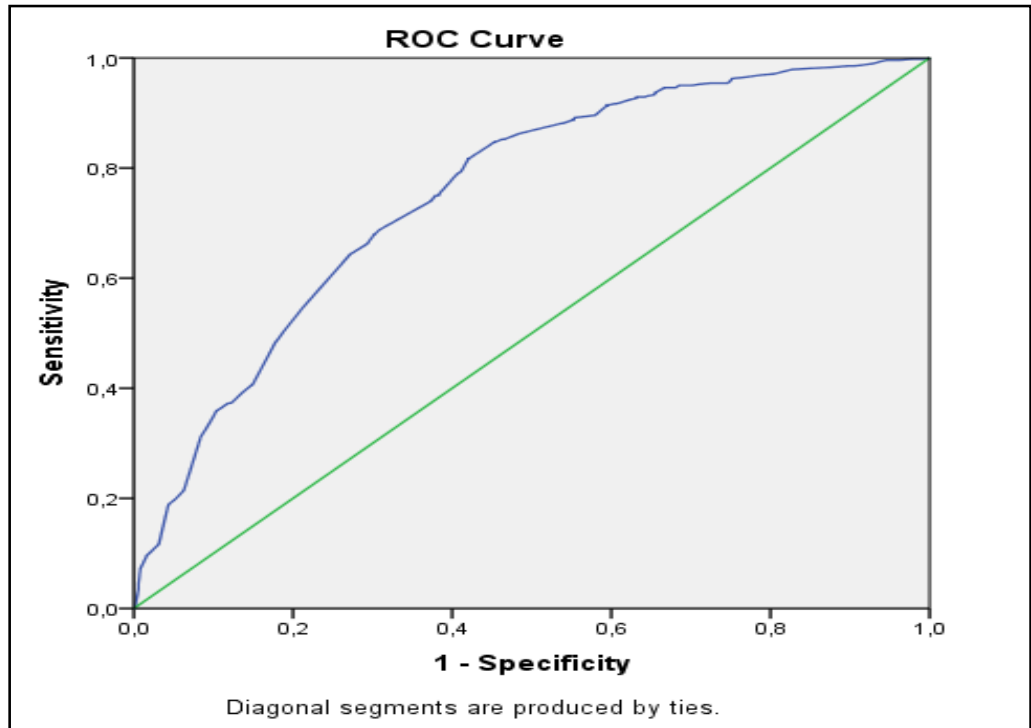

Sumber : Sakernas 2018 (diolah).

Gambar 2. Hasil pengolahan kurva ROC

Tabel 5 Hasil luas area dibawah kurva ROC

\begin{tabular}{lllll}
\hline Area & $\begin{array}{l}\text { Std. } \\
\text { Error }\end{array}$ & Asymptotic Sig. & & \multicolumn{2}{l}{ Asymptotic $95 \%$ Confidence Interval } \\
\cline { 4 - 5 } & & Lower Bound & Upper Bound \\
\hline 0,754 & 0,012 & 0,000 & 0,731 & 0,777 \\
\hline
\end{tabular}

Berdasarkan selang kepercayaan 95\%, luas area dibawah kurva ROC berkisar antara 0,73 hingga 0,777 . Selang kepercayaan yang tidak terlalu lebar menunjukkan bahwa luas area dibawah kurva ROC yang dihasilkan sudah cukup presisi.

Uji Simultan

Berdasarkan hasil pengolahan didapatkan nilai G sebagai berikut :

$$
\begin{aligned}
& G=-2 \ln \left(\frac{L o}{L p}\right) \sim \chi^{2}{ }_{(0,05,7)} \\
& G=314.984
\end{aligned}
$$

Dengan nilai $p$-value sebesar : 0,000

Nilai dari $p$-value $<\mathrm{a}(0,05)$ maka keputusan yang dihasilkan adalah tolak $\mathrm{H}_{0}$. Ini berarti dengan tingkat signifikansi 5 persen terdapat cukup bukti untuk menyatakan secara bersama-sama terdapat minimal satu variabel yang signifikan memengaruhi status angkatan kerja pemuda di Banten. 


\section{Uji Parsial (Wald test)}

Dari hasil pengujian simultan dapat disimpulkan bahwa minimal terdapat satu variabel independen yang memengaruhi status kerja pemuda di provinsi Banten. Untuk dapat mengetahui variabel mana saja yang berpengaruh terhadap status kerja pemuda, maka dapat dilanjutkan dengan uji selanjutnya yaitu uji parsial. Uji parsial dilakukan untuk mengetahui pengaruh masingmasing variabel independen terhadap status kerja pemuda di provinsi Banten. Uji yang digunakan adalah uji Wald.

Tabel 5. Hasil Pengujian Parsial

\begin{tabular}{|c|c|c|c|c|c|c|c|c|}
\hline & $\begin{array}{l}\text { Dummy } \\
\text { Variable }\end{array}$ & Variabel & B & S.E. & Wald & Df & Sig. & $\operatorname{Exp}(B)$ \\
\hline (1) & (2) & (3) & (4) & (5) & (6) & (7) & (8) & (9) \\
\hline 1 & D1 & Jenis Kelamin (1) & 0,257 & 0,123 & 4,376 & 1 & $0,036^{*}$ & 1,293 \\
\hline \multirow{3}{*}{2} & - & Kelompok umur & & 0,085 & 85,063 & 2 & $0,000 *$ & \\
\hline & $\mathrm{D} 21$ & Kelompok umur (1) & $-0,882$ & 0,140 & 39,535 & 1 & 0,000 & 0,414 \\
\hline & D22 & Kelompok umur (2) & $-1,555$ & 0,170 & 83,966 & 1 & 0,000 & 0,211 \\
\hline 3 & D3 & $\begin{array}{l}\text { Status Kepala Rumah } \\
\text { Tangga (1) }\end{array}$ & $-0,584$ & 0,369 & 2,504 & 1 & 0,114 & 0,558 \\
\hline 4 & D4 & Status Kawin (1) & 1,398 & 0,196 & 50,847 & 1 & $0,000 *$ & 4,048 \\
\hline 5 & D5 & Pendidikan Tertinggi (1) & $-0,442$ & 0,126 & 12,323 & 1 & $0,000 *$ & 0,643 \\
\hline 6 & D6 & $\begin{array}{l}\text { Klasifikasi Wilayah Tempat } \\
\text { Tinggal (1) }\end{array}$ & $-0,476$ & 0,123 & 14,957 & 1 & $0,000 *$ & 0,621 \\
\hline 7 & D7 & Pengalaman Kerja (1) & $-0,181$ & 0,119 & 2,311 & 1 & 0,128 & 0,834 \\
\hline 8 & - & Constant & $-0,997$ & 0,267 & 13,981 & 1 & $0,000 *$ & 0,369 \\
\hline
\end{tabular}

Keterangan : *) : Signifikan pada alfa 5 persen $(0,05)$

Berdasarkan Tabel 5 diatas, kita bisa mengetahui variabel mana saja yang berpengaruh terhadap status kerja pemuda di provinsi Banten tahun 2018. Variabel independen dinyatakan berpengaruh terhadap variabel dependen ketika nilai $p$-value $(\mathrm{sig})<\mathrm{a}(0,05)$. Ini berarti bahwa variabel tersebut berpengaruh signifikan terhadap status angkatan kerja pemuda. Berdasarkan tabel 4 kita bisa mengetahui bahwa Status kepala rumah tangga dan Pengalaman kerja tidak berpengaruh secara signifikan terhadap status kerja pemuda provinsi Banten pada tahun 2018.

Jenis kelamin memiliki pengaruh yang siginifikan dan positif terhadap status kerja pemuda. Dengan menggunakan jenis kelamin perempuan sebagai kategori referensi, nilai Odds ratio untuk variabel jenis kelamin adalah 1,29. Berdasrkan angka ini dapat diartikan bahwa pemuda dengan jenis kelamin laki-laki memiliki kecenderungan sebesar 1,29 kali untuk menjadi pengangguran dibandingkan dengan pemuda berjenis kelamin perempuan, dengan asumsi variabel lain konstan.

Pada variabel kelompok umur terdapat tiga kategori, sehingga diperlukan dua variabel dummy untuk menjelaskannya. Pada penelitian ini berdasarkan nilai signifikansi, kedua variabel dummy berpengaruh signifikan terhadap status kerja pemuda. Kelompok umur (1) menunjukkan pemuda berusia 20-24 dan kelompok umur (2) menunjukkan pemuda berusia 25-30 tahun dengan kategori referensi adalah kelompok umur 16-19 tahun. . Odds ratio dari nilai $\exp (\beta)$ pada kelompok umur 2024 menunjukkan nilai $0,414(1 / 0,414=2,41)$ dengan kategori referensi kelompok umur $16-19$ tahun. Berdasarkan angka ini dapat diartikan bahwa pemuda berusia 16-19 tahun 2,41 kali lebih cenderung untuk menjadi pengangguran dibandingkan dengan pemuda berusia antara 20-24 tahun. Dan nilai odds ratio pada kelompok umur 25-30 tahun menunjukkan nilai 0,211 $(1 / 0,211=4,74)$ dengan menggunakan kategori referensi kelompok umur 16-19 tahun. Berdasarkan angka tersebut dapat diartikan bahwa pemuda berusia 16-19 tahun cenderung untuk menjadi pengangguran 4,74 kali dibandingkan dengan pemuda berusia 25-30 tahun. 
Status kawin berpengaruh secara signifikan terhadap status kerja pemuda. Berdasarkan tabel 4.6 variabel status kawin memiliki nilai koefisien sebesar 1,398. Nilai yang positif menunjukkan bahwa status kawin memiliki arah hubungan yang positif terhadap pengangguran pemuda. Sementara nilai Odds ratio nya adalah sebesar 4,04. Kategori referensi pada status kawin adalah pernah kawin. Nilai ini memiliki arti bahwa pemuda yang belum pernah kawin di provinsi Banten cenderung 4 kali lebih tinggi untuk menjadi pengangguran dibandingkan yang berstatus pernah kawin.

Pendidikan tertinggi yang ditamatkan berpengaruh secara signifikan terhadap status kerja pada pemuda di provinsi Banten. Nilai koefisien yang tertera untuk variabel pendidikan tertinggi berdasarkan tabel 4.6 adalah sebesar $-0,442$. Hal ini berarti pendidikan tertinggi yang ditamatkan memiliki pengaruh negatif terhadap status pengangguran pemuda. Nilai Odds ratio adalah sebesar 0,643 dengan menggunakan tamatan SMP ke bawah sebagai kategori referensi. Artinya adalah, bahwa pemuda yang tamatan tertingginya adalah SMA ke atas, cenderung 1,534 kali untuk menjadi pengangguran dibandingkan dengan pemuda yang tamatan tertingginya adalah SMP kebawah.

Klasifikasi wilayah tempat tinggal berpengaruh secara signifikan terhadap status kerja pada pemuda di provinsi Banten. Pada tabel 4.6, nilai koefisien pada variabel klasifikasi wilayah adalah sebesar $-0,476$. Koefisien ini berarti bahwa klasifikasi wilayah tempat tinggal memiliki pengaruh yang negatif terhadap status kerja pemuda. Masih dari tabel 4.6, nilai Odds ratio pada variabel ini adalah 0,621 dan untuk mempermudah interpretasi masi di ubah menjadi 1/0,621 $=1,609$ dengan kategori referensi nya adalah pedesaan. Ini dapat diartikan bahwa pemuda yang tinggal di wilayah pedesaan cenderung untuk menjadi pengangguran 1,6 kali lebih tinggi dibandingkan dengan pemuda yang tinggal di wilayah perkotaan.

\section{KESIMPULAN}

Berdasarkan hasil dan pembahasan yang telah dipaparkan sebelumnya, didapatkan kesimpulan bahwa pada tahun 2018, angkatan kerja Pemuda di Provinsi Banten 22,64 persen berstatus sebagai pengangguran, dan 77,36 persen berstatus bukan pengangguran. Persentase pengangguran pemuda Banten tertinggi terjadi pada angkatan kerja berjenis kelamin laki-laki, belum pernah kawin, bukan kepala rumah tangga, tinggal di wilayah pedesaan, berusia antara 16-19 tahun, berpendidikan terakhir SMA ke atas dan tidak memiliki pengalaman kerja sebelumnya. Angkatan kerja pemuda yang berjenis kelamin laki-laki, belum pernah kawin, dan tinggal di wilayah pedesaan memiliki kecenderungan yang lebih besar untuk menjadi pengangguran. Sementara angkatan kerja yang memiliki tingkat pendidikan tertinggi kurang sama dari SMP memiliki kecenderungan yang lebih kecil untuk menjadi pengangguran. Pemuda dengan kelompok umur 16-19 tahun memiliki kecenderungan yang lebih tinggi untuk menjadi pengangguran dibandingkan pemuda dengan kelompok umur yang lebih tua.

Variabel yang memiliki pengaruh terhadap status kerja angkatan kerja pemuda di Banten adalah variabel jenis kelamin, kelompok umur, status kawin, pendidikan tertinggi, dan klasifikasi wilayah tempat tinggal. Sementara variabel status kepala rumah tangga dan pengalaman kerja tidak terdapat cukup bukti untuk menyatakan mereka berpengaruh terhadap pengangguran pemuda pada penelitian ini. Berdasarkan variabel yang diketahui mempengaruhi pengangguran di Banten maka dapat disimpulkan terdapat banyak Pekerjaan rumah dari pemerintah daerah untuk dapat memenuhi target kelima dari tujuan ke tujuh dari SDG'S yaitu untuk mampu memberikan pekerjaan yang layak dan memenuhi utamanya bagi kaum muda.

\section{DAFTAR PUSTAKA}

Agresti, A. (2000). Categorical Data Analysis (2nd ed). New York: John Wiley \& Sons. Badan Pusat Statistik. (2013). Proyeksi Penduduk Indonesia 2010-2035. Jakarta : BPS Badan Pusat Statistik. (2018). Keadaan Pekerja di Indonesia Agustus 2018. Jakarta: BPS. Badan Pusat Statistik. (2018). Statistik Kesejahteraan Rakyat 2018. Jakarta: BPS. Badan Pusat Statistik. (2018). Statistik Pemuda Indonesia 2018. Jakarta: BPS. 
Fila, D.T., Mansingh, J.Paul, Legesse,Warkaw.(2016) Determinants of Youth Unemployment: The Case of Ambo Town, Oromia, Ethiopia. International Journal of Economics and Business Management,162-169.

Hosmer, D. W. \& Lemeshow, S..(2000). Applied Logistic Regression Second Edition. New Yok:John Wiley \& Sons.

Maryati, S. (2015). Dinamika pengangguran terdidik: tantangan menuju bonus demografi di Indonesia. ECONOMICA JOURNAL: Research of Economic And Economic Education, 3(2),124-136.

Mankiw, N. (2012). Macroeconomics. New York : Worth Publishers.

Msigwa, R., \& Kipesha, E. F. (2013). Determinants of youth unemployment in developing countries: Evidences from Tanzania.

Nanda, Kwinta R. (2018). Faktor Individual dan Konstekstual yang Memengaruhi Pengangguran Usia Muda di Indonesia tahun 2017[Skripsi]. Jakarta : Politeknik Statistika STIS.

Ningrum, V. (2016). Tantangan Sosial-Ekonomi Pengangguran Usia Muda di Indonesia. Jurnal Kependudukan Indonesia, 8(2), 117-126.

RI (Republik Indonesia). (2009). Undang Undang No. 40 Tahun 2009 Republik Indonesia Tentang Kepemudaan. Sekretariat Negara. Jakarta.

Shita, A. \& Dereje, M. (2018) Determinants of Urban Youth Unemployment; Evidence From East Gojjam Zone, Ethiopia. International Journal of Economic Development Volume 11,245-265. 